\title{
MICROWAVE CONVERSION OF PLANTATION GROWN BLUE GUM (Eucalyptus globulues L'Herit) WOOD TO TORGVIN AND IMPREGNATION WITH A METAL ALLOY
}

\author{
GRIGORY TORGOVNIKOV, PETER VINDEN \\ and BRUNO BALBONY \\ Department of Forest and Ecosystem Science \\ The University of Melbourne \\ 4 Water St. \\ Creswick, Victoria 3363 \\ Australia \\ e-mail: grigori@unimelb.edu.au
}

\begin{abstract}
Microwave modification converts wood into a highly porous material Torgvin with numerous cavities and dramatic changes to the physical and mechanical properties of wood including very high permeability. Impregnation of Torguin with a low melting point metal alloy fills the voids with metal. Strength property values of the newly formed Vintorg-metal range between the property values of wood and Torguin. Vintorg-metal has new properties compared to natural wood: high electro-conductivity, high thermo-conductivity, very high density, and other physical properties that require further study. New specific properties of the Vintorg-metal opens up new fields of potential application.
\end{abstract}

Keywords and phrases: metal alloy, microwave wood modification, microwave applicator, Torgvin, Vintorg-metal.

Received December 12, 2014

(C) 2015 Scientific Advances Publishers 


\section{Introduction}

A number of wood species have a very low permeability causing problems during timber processing. Plantation grown Blue gum (Eucalyptus globulues) is a fast growing species with variable wood properties including refractory (difficult to impregnate) heartwood. Microwave modification [2, 4, 5] can change Blue gum wood properties and open new potential applications for this species.

Green wood readily absorbs microwave (MW) energy because of its high moisture content. The passage of MW energy through wood results in a very high release of energy from within the material. When intense levels of MW energy are applied to wood, steam is generated within the wood cells. Under high internal steam pressure, the pit membranes in cell walls, tyloses in vessels and the weak ray cells rupture to form pathways for easy transportation of liquids and vapours. Increases in the intensity of applied microwave further increases internal steam pressure, resulting in the formation of narrow voids in the radial-longitudinal planes [5]. A several thousand-fold increase in wood permeability in the radial, tangential, and longitudinal directions can be achieved in species previously found to be impermeable to liquids and gases [2]. MW wood modification improves liquid impregnation and uptake. It is possible to use microwave wood modification to enhance existing processes and to develop entirely new processing and product options for wood.

High degrees of MW modification can convert wood into a highly porous material with numerous cavities mainly in the radial - longitudinal plane. The highly porous material was named "TorguinTM" [3]. Torguin can be used as intermediate material for the production of new composite materials, for example, "VintorgTM" [6] by impregnation with resins, plastics, and metal alloys.

The research objectives include:

- a study of the effects of MW modification on Blue gum wood structure and properties;

- characterisation of the effect of impregnating MW modified wood with a metal alloy. 


\section{Material and Methods}

\subsection{Material}

Forty boards of plantation grown Blue gum green sawn timber measuring $42 \times 84 \times 2500 \mathrm{~mm}$ with an initial moisture content ranging from $78-108 \%$ were used for experimentation. Wood density (for wood moisture contents of $8-12 \%$ ) ranged from 532 to $858 \mathrm{~kg} / \mathrm{m}^{3}$.

\subsection{Equipment and experimental procedure}

\subsubsection{MW wood modification}

A 60kW MW experimental installation (Figure 1) was used for wood modification. It includes an MW power supply, waveguides, tuners, Y-type applicator (Figure 2), tunnel, roller feeding system, and air dynamic system for the removal of vapours from the applicator and prevention of water condensation on the walls of the applicator.

Technical data of MW installation:

- MW power - 6-60kW.

- Frequency - 2.45GHz.

- Max dimensions of timber $-50 \times 100 \mathrm{~mm}$.

- Feed speed -6-50 mm/sec.

- Air heating power $-13 \mathrm{~kW}$.

- Air temperature $-20-150^{\circ} \mathrm{C}$. 


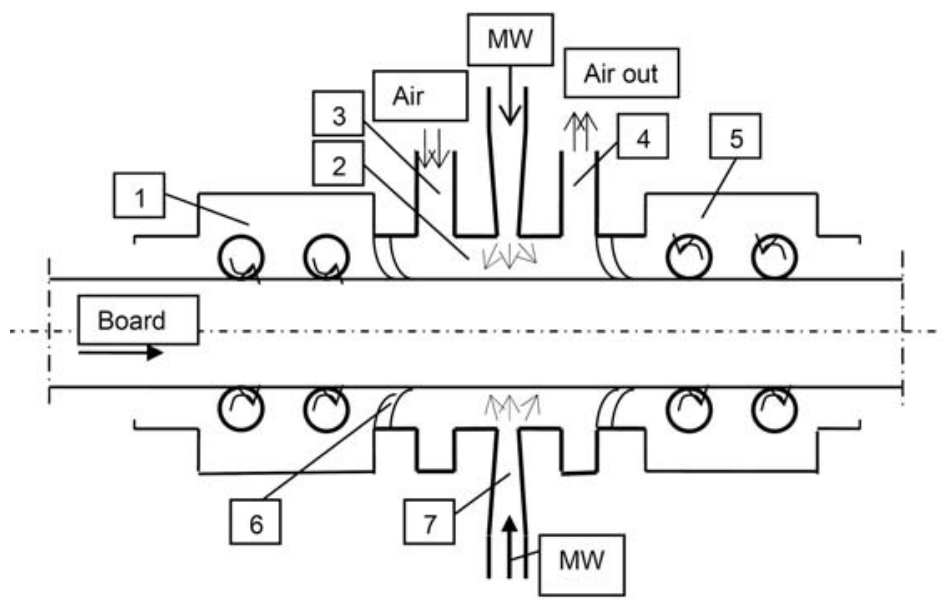

Figure 1. Diagram of MW experimental plant for wood modification: (1) in-feed mechanism; (2) MW applicator; (3) air supply inlet; (4) air outlet; (5) out-feed mechanism; (6) MW suppressor; and (7) MW radiator for energy supply to applicator.

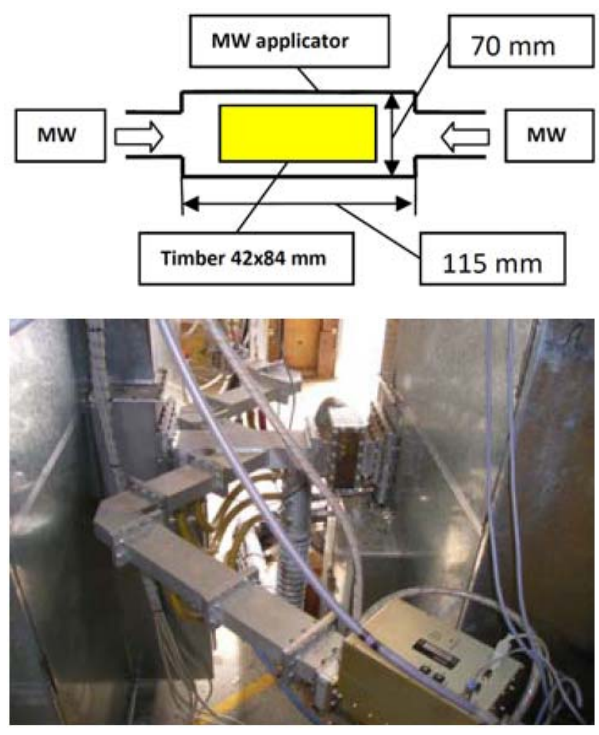

Figure 2. Diagram and photo of MW applicator for wood modification (cross-section $70 \times 115 \mathrm{~mm}$ ). MW power at frequency $2.45 \mathrm{GHz}$ is supplied from two sides of the applicator. 
During preliminary tests, the required parameters and schedule of MW wood modification for Torgvin manufacturing were determined:

MW power $-32.5 \mathrm{~kW}$ supplied from two sides of the applicator.

Applied MW energy $-275 \mathrm{kWh} / \mathrm{m}^{3}\left(990 \mathrm{MJ} / \mathrm{m}^{3}\right)$.

Specific MW power applied to wood in applicator $-46 \mathrm{~W} / \mathrm{cm}^{3}$.

Electric field strength vector E orientation - perpendicular to the wood grain.

Board position - in the middle of the applicator, size $42 \mathrm{~mm}$ is vertical.

Roller conveyor speed $-9.3 \mathrm{~mm} / \mathrm{sec}$.

Ventilation air temperature $-110^{\circ} \mathrm{C}$.

The boards were processed during the movement through the MW applicator. The criteria for the evaluation of the degree of MW wood modification was the uniformity of the void distribution through the cross-section of the material. More than $85-90 \%$ of cross-section area had visible checks, meaning that the sample had good degree of modification.

\subsubsection{Sample impregnation with alloy}

Dry Blue gum Torgvin (10 samples measuring $20 \times 20 \times 340 \mathrm{~mm}$ ) were used for impregnation with the metal alloy (Company Belmont alloy No. 2431, bismuth/lead/tin/cadmium). The alloy included a mixture of metals comprising bismuth $42.5 \%$, lead $37.7 \%$, tin $11.3 \%$, and cadmium $8.5 \%$. The alloy melting point was $74^{\circ} \mathrm{C}$ and density $-7400 \mathrm{~kg} / \mathrm{m}^{3}$. Technical specifications for the alloy included a Brinell hardness of $51 \mathrm{MPa}$, and short term tensile strength of $37.2 \mathrm{kPa}$.

A pressure vessel with heater was used for Torgvin sample impregnation. Wood samples were submerged into the metal alloy at a temperature of approximately $120^{\circ} \mathrm{C}$. The container containing the samples were then placed into a pressure vessel for impregnation. After 
preliminary testing, the following schedule was applied for impregnation of the samples with alloy:

$\begin{array}{lll}\text { Vacuum } & -85 \mathrm{kPa} & 5 \mathrm{~min} \\ \text { Pressure } & 1200 \mathrm{kPa} & 20 \mathrm{~min}\end{array}$

Temperature in vessel $\quad 120^{\circ} \mathrm{C}$.

\subsubsection{Sample strength tests}

MOR (modulus of rupture), MOE (modulus of elasticity), and surface hardness were used to characterise the strength properties of Blue gum wood, Torgvin, and Vintorg-metal. Australian standards wood testing procedures [1] were applied using universal strength testing machines (Hounsfield HK10-C) and Instron Materials Testing System (Model No. 5569 , load capacity $50 \mathrm{kN}$ ) (see Figure 3 ).

Samples for strength testing measuring $20 \times 20 \times 340 \mathrm{~mm}$ were made from wood (56pc), Torgvin (71pc), and Vintorg-metal (10pc). During the tests, the load was applied to the samples in the radial (R), tangential (T), and $45^{\circ}$ angle in the radial and tangential (CR) directions. The moisture content of samples during testing ranged from 8-12\%.
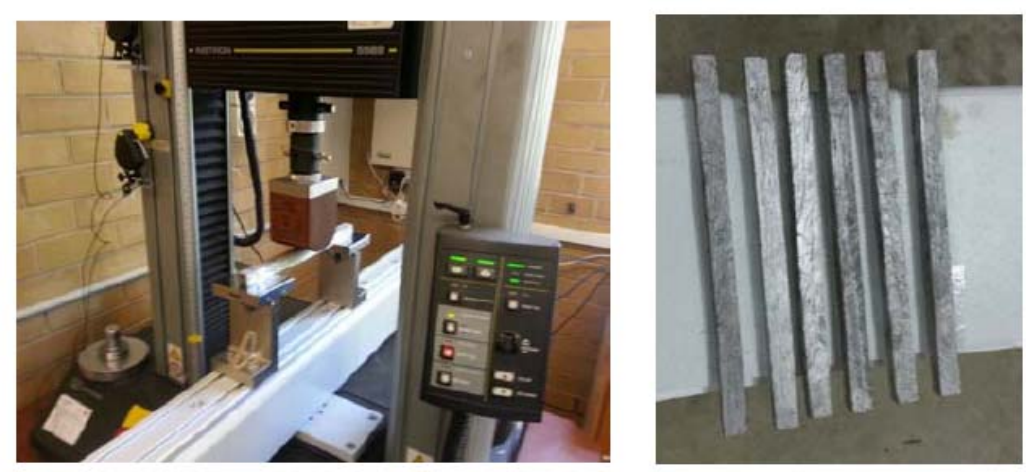

Figure 3. Instron materials testing system (Model No. 5569, load capacity $50 \mathrm{kN}$ ) and Vintorg-metal samples. 


\section{Result and Discussion}

\subsection{Torgvin structure}

Conversion of Blue gum wood to Torgvin provided macro-changes in wood structure: rupturing of wood cell pore membranes, resin boiling and replacement, destruction of tyloses, rupturing of ray cells, rupturing of libriform fibre walls and walls of vessels, and the formation of cavities (micro-voids) primarily in radial-longitudinal planes. Figures 4 and 5 illustrate Blue-gum / Torgvin structure.
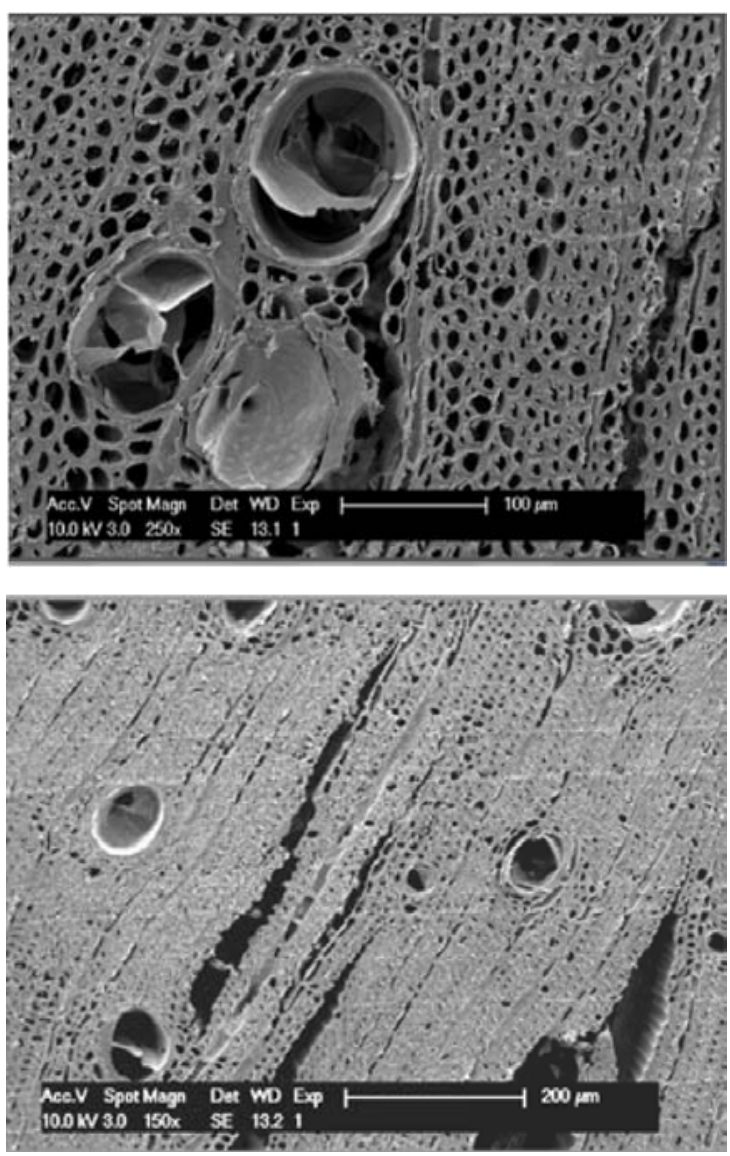

Figure 4. Blue-gum after high degree MW wood modification. Top broken tyloses in vessels: bottom- checks and broken rays (thin dark lines). 
High degrees of MW modification result in the formation of different sized voids in the wood. Voids form on the base of ruptured rays that then extend in the tangential, radial, and longitudinal directions. The number of voids depend on the number of rays in the specific wood volume. The higher the percentage ray tissue the greater the number of cavities formed.
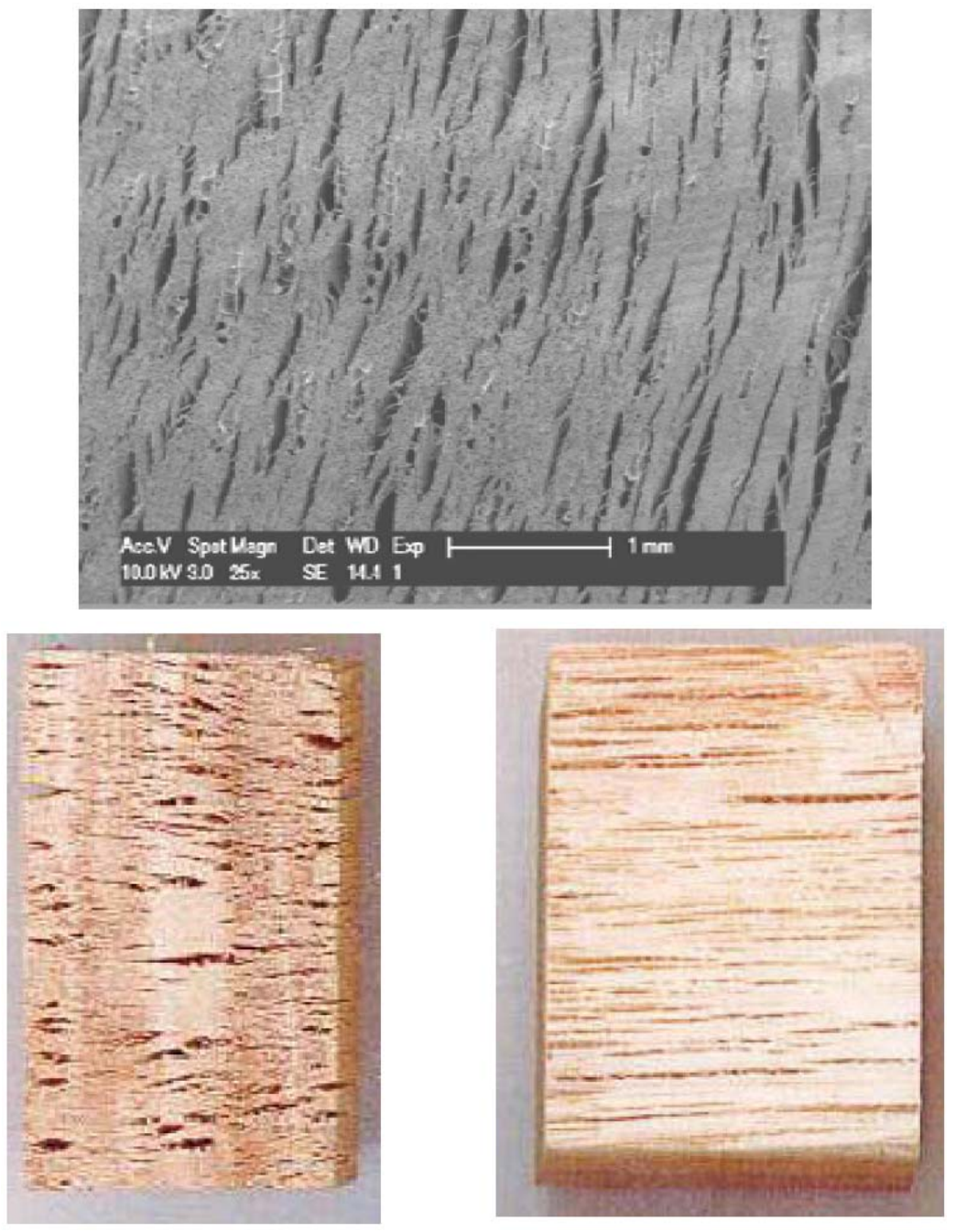

Figure 5. Voids in Torgvin manufactured in Blue gum.

The sizes of voids and their distribution in Torguin are shown in the Table 1. 
Table 1. Sizes of voids and their distribution in Torgvin from plantation grown Blue gum

\begin{tabular}{|c|c|c|c|c|c|c|c|}
\hline $\begin{array}{l}\text { Void width } \\
\text { in } \\
\text { tangential } \\
\text { direction in } \\
\text { the range }\end{array}$ & $\begin{array}{c}\text { Percent of } \\
\text { void number } \\
\text { in tangential } \\
\text { direction }\end{array}$ & $\begin{array}{l}\text { Void length } \\
\text { in radial } \\
\text { direction }\end{array}$ & $\begin{array}{l}\text { Percent of } \\
\text { void number } \\
\text { in radial } \\
\text { direction }\end{array}$ & $\begin{array}{l}\text { Void length } \\
\text { in } \\
\text { longitudinal } \\
\text { direction }\end{array}$ & $\begin{array}{c}\text { Percent of void } \\
\text { number in } \\
\text { longitudinal } \\
\text { direction }\end{array}$ & $\begin{array}{l}\text { Distance } \\
\text { between } \\
\text { voids in } \\
\text { tangential } \\
\text { direction }\end{array}$ & $\begin{array}{l}\text { Percent of } \\
\text { distances } \\
\text { between } \\
\text { voids in } \\
\text { tangential } \\
\text { direction }\end{array}$ \\
\hline $\mathrm{mm}$ & $\%$ & $\mathrm{~mm}$ & $\%$ & $\mathrm{~mm}$ & $\%$ & $\mathrm{~mm}$ & $\%$ \\
\hline$<0.5$ & 81.54 & $<1.0$ & 8.0 & $<5$ & 9.5 & $<2$ & 67.3 \\
\hline $0.5-1.0$ & 14.31 & $1-5$ & 62.5 & $5-10$ & 26.9 & $2-5$ & 26.7 \\
\hline $1-2$ & 3.98 & $5-10$ & 22.5 & $10-20$ & 39.1 & $5-10$ & 4.9 \\
\hline $2-4$ & 0.11 & $10-20$ & 6.0 & $20-30$ & 15.7 & $10-20$ & 1.0 \\
\hline \multirow[t]{3}{*}{$4-6$} & 0.06 & $>20$ & 1.0 & $30-40$ & 6.3 & $>20$ & 0.1 \\
\hline & & & & $40-50$ & 1.5 & & \\
\hline & & & & $>50$ & 1.0 & & \\
\hline
\end{tabular}


About $96 \%$ of voids have widths less than $1.0 \mathrm{~mm}$; $93 \%$ of voids have lengths in the radial direction less than $10 \mathrm{~mm}$, and $76 \%$ of voids in longitudinal direction have lengths up to $20 \mathrm{~mm}$. Distances up to $5 \mathrm{~mm}$ between voids in the tangential direction form $94 \%$ of all visible distances. There are many "invisible" or very narrow checks (for example, partly destroyed rays) in the wood. However, their assessment requires a special study.

MW Blue gum modification converts wood into a highly porous material with altered properties compared to unmodified wood: improved permeability, reduced density, reduced heat conductivity (better heat insulation), reduced shrinkage and swelling, and improved acoustic properties (better sound insulation). The special physical properties of Torgvin open up a number of new fields for the application of wood materials. One application for Torgvin is the production of a new composite material Vintorg. Vintorg is manufactured from Torgvin by impregnating with resin, followed by pressing and curing [4].

\subsection{Vintorg-metal structure}

During pressure impregnation, a liquid alloy penetrates and fills the voids, cracks, broken rays, and vessels in Torgvin to form a wood-metal composite structure. Figure 6 illustrates radial and tangential cuts in Vintorg-metal samples. Figure 7 illustrates cross-cut samples. Light colour dots in Figure 7 are vessels filled by metal, light colour lines are broken rays and voids filled with metal. 

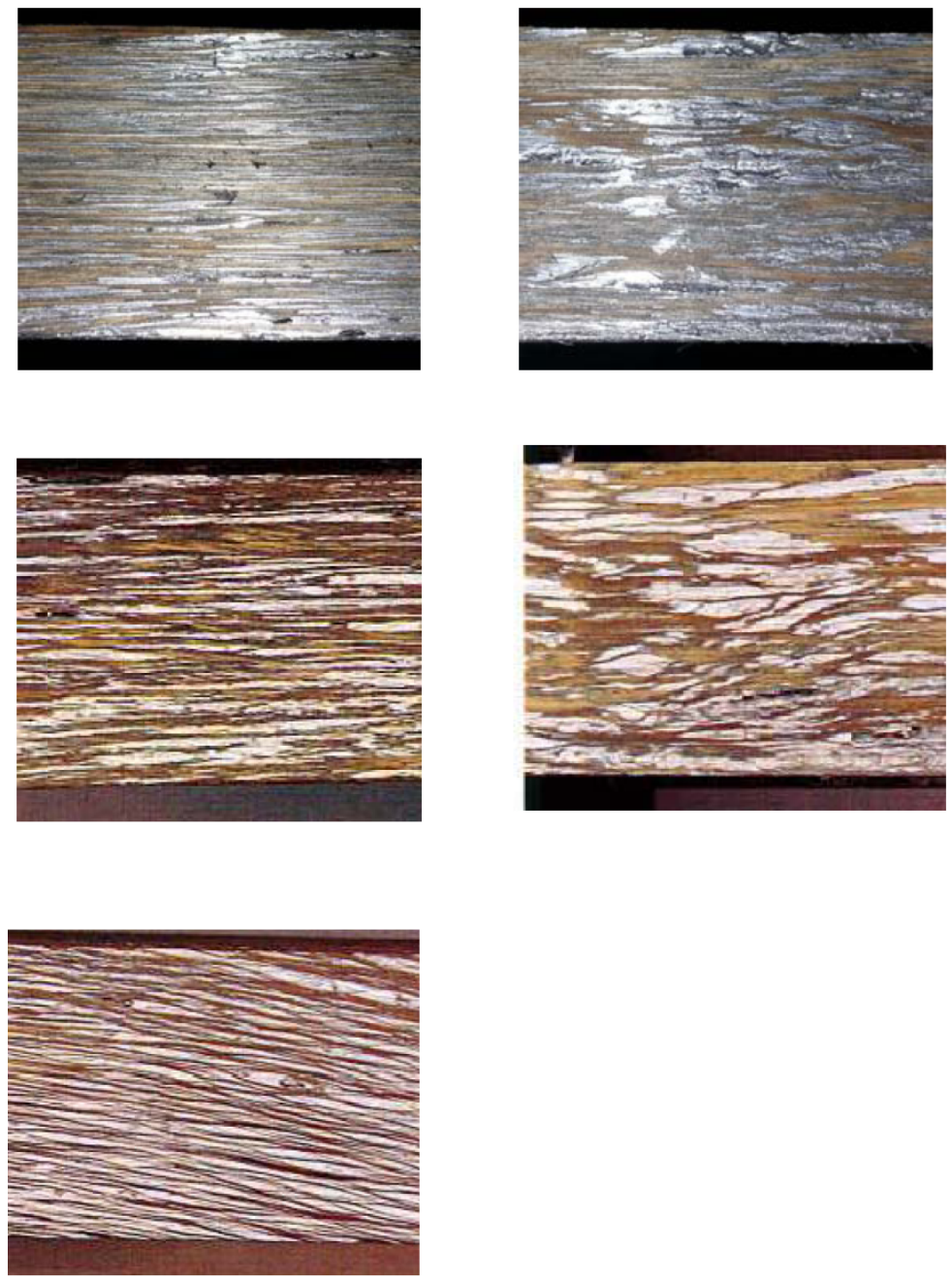

Figure 6. Vintorg-metal sample tangential (left) and radial (right) cuts. Vertical size $20 \mathrm{~mm}$. 

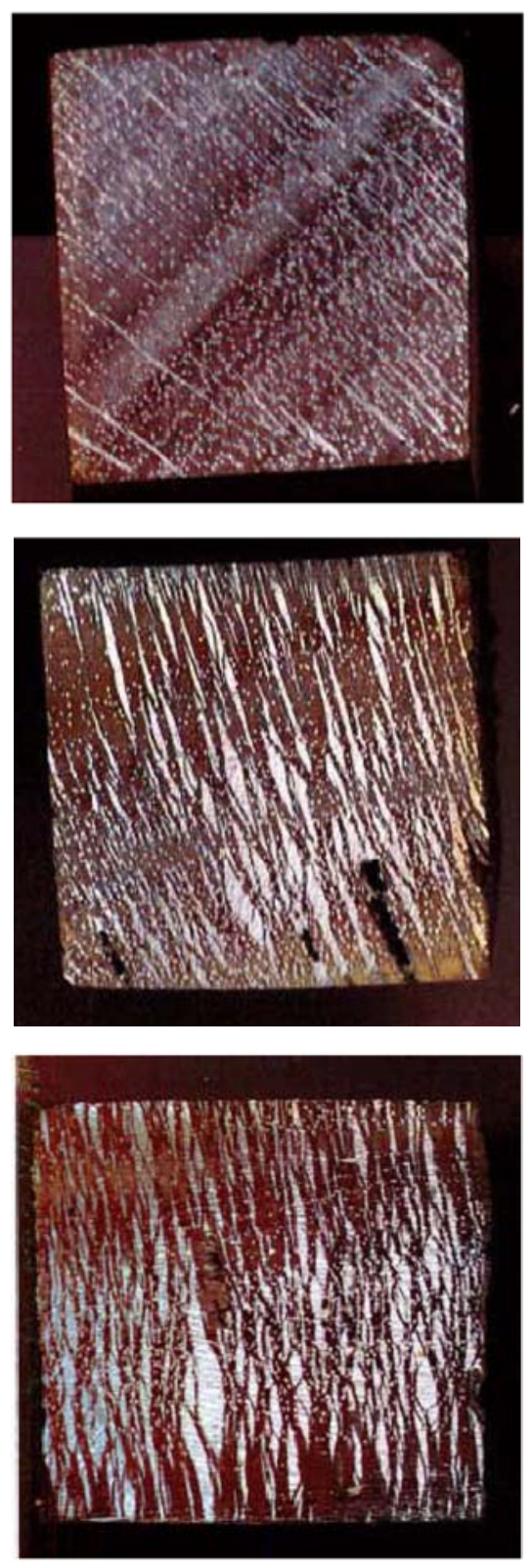

Figure 7. Vintorg-metal sample cross cuts. Sample size $20 \times 20 \mathrm{~mm}$. Light colour dots are vessels filled by metal, light colour lines are broken rays and voids filled by metal. 


\subsection{Material properties}

\section{(a) Torgvin density}

Density is one of the most important wood properties which determines other properties. MW wood modification reduces wood density depending on the species and the degree of modification. Torgvin manufactured from Blue gum has an average density $637 \mathrm{~kg} / \mathrm{m}^{3}$ (CV $11.6 \%)$ at a moisture content $8-12 \%$ compared to an original wood density

of $697 \mathrm{~kg} / \mathrm{m}^{3}$ (CV 10.7\%). Density reduction after MW modification is approximately $8.6 \%$.

Voids in Torgvin occur in the radial and longitudinal planes while size increases mainly in the tangential direction. The level of density reduction is a function of MW energy applied to the wood.

\section{(b) Torgvin strength}

MW modification of Blue-gum results in a significant loss of mechanical strength. Conversion of wood to Torgvin leads to substantial loss in MOR, MOE, and hardness depending on the applied MW processing schedule. MW treatment at an applied energy of $275 \mathrm{kWh} / \mathrm{m}^{3}$ $\left(990 \mathrm{MJ} / \mathrm{m}^{3}\right)$ shows (Table 2, Figure 8) a reduction in MOR in the radial direction of 2.3 times and in the tangential direction, 2.8 times compared to natural wood. Loss of MOE in the radial direction is 1.6 and in the tangential direction 1.9 times the original wood. Torgvin hardness is reduced in the radial direction by 2.8 and in the tangential direction by 2.3 times compared to the original wood. 
Table 2. Comparison of mechanical properties Blue gum Torguin and wood

\begin{tabular}{|c|c|c|c|c|c|c|c|c|c|}
\hline & \multicolumn{3}{|c|}{ MOR, MPa } & \multicolumn{3}{|c|}{ MOE, MPa } & \multicolumn{3}{|c|}{ Hardness, $\mathrm{MPa}$} \\
\hline $\begin{array}{l}\text { Load application } \\
\text { directions }\end{array}$ & Wood & Torgvin & $\begin{array}{l}\text { Wood/ } \\
\text { Torgvin ratio }\end{array}$ & Wood & Torgvin & $\begin{array}{l}\text { Wood/ } \\
\text { Torgvin } \\
\text { ratio }\end{array}$ & Wood & Torgvin & $\begin{array}{l}\text { Wood/ } \\
\text { Torgvin ratio }\end{array}$ \\
\hline Radial (R) & 119 & 52 & 2.29 & 12390 & 7560 & 1.64 & 47 & 17 & 2.76 \\
\hline Tangential (T) & 117 & 42 & 2.79 & 9150 & 4740 & 1.93 & 45 & 20 & 2.25 \\
\hline $\begin{array}{l}\text { Under the angle } 45^{\circ} \\
\text { to the radial and } \\
\text { tangential } \\
\text { directions (CR) }\end{array}$ & 107 & 51 & 2.10 & 11110 & 6090 & 1.82 & 43 & 19 & 2.26 \\
\hline $\begin{array}{l}\text { Transverse - average } \\
\text { of the radial (R), } \\
\text { tangential (T) and } \\
\text { under the angle } 45^{\circ} \\
\text { (CR) directions }\end{array}$ & 114 & 48 & 2.38 & 10880 & 6130 & 1.77 & 45 & 19 & 2.37 \\
\hline
\end{tabular}



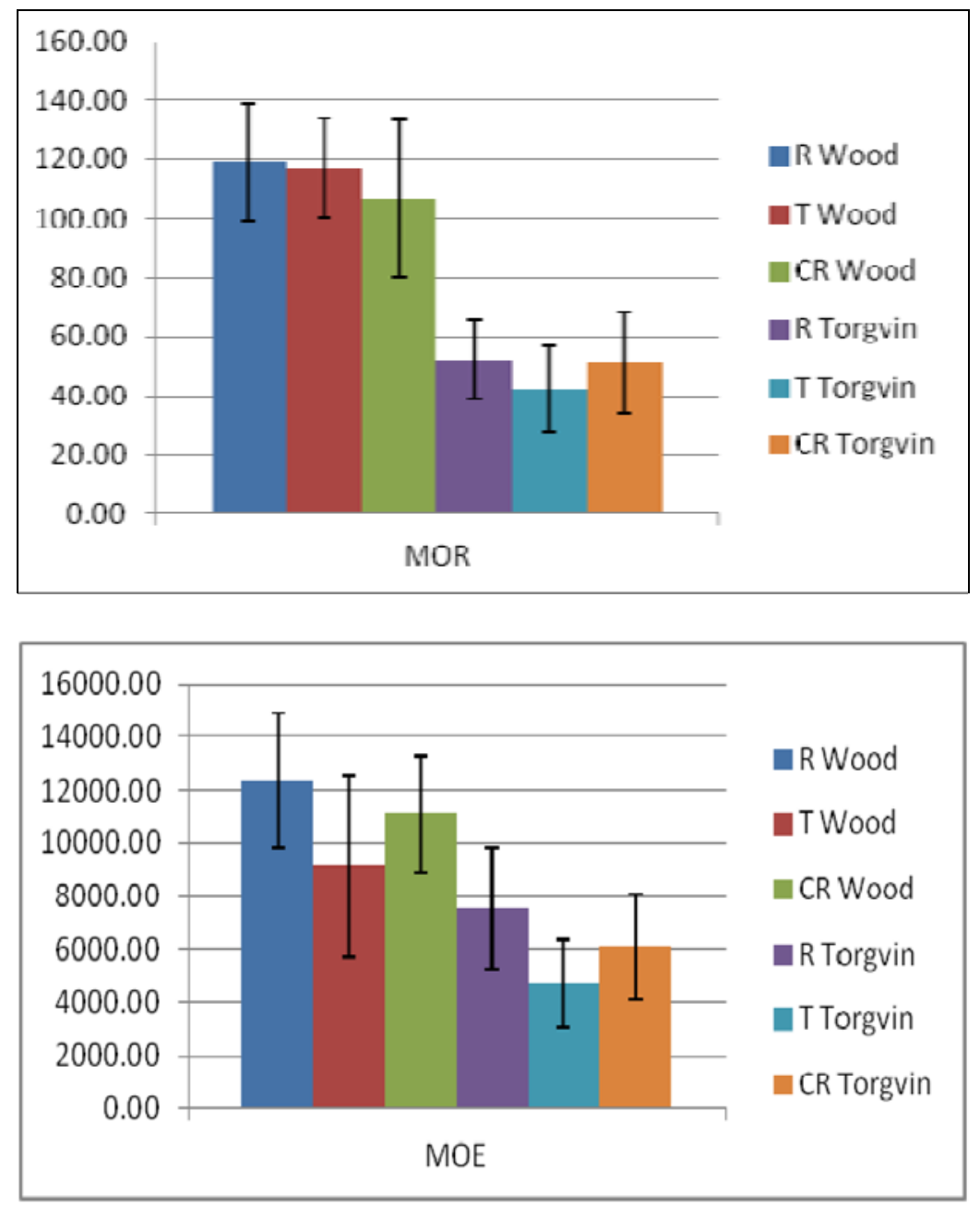

Figure 8. Modulus of rupture (MOR, $\mathrm{MPa}$ ) and modulus of elasticity (MOE, MPa) of Blue gum wood and Torgvin in the radial (R), tangential $(\mathrm{T})$, and $45^{\circ}$ angle in the radial and tangential directions (CR). Average wood density: $697 \mathrm{~kg} / \mathrm{m}^{3}$, Torgvin: $637 \mathrm{~kg} / \mathrm{m}^{3}$ (at $\mathrm{MC}=8-12 \%$ ).

The more significant reductions in MOR and MOE in tangential compared to radial grain directions is due to the fact that voids occur in the radial-longitudinal planes. Variation in Torgvin mechanical properties is significantly higher compared to wood. The coefficient of 
variation (CV) of Torguin MOR is $31.9 \%$, compared to the original wood $(\mathrm{CV}=19.9 \%)$. Torguin $\mathrm{MOE}$ is $37.3 \%$, compared to the original wood $(\mathrm{CV}=20.8 \%)$. More significant surface hardness reductions in the radial direction compared to the tangential face is explained by the easier penetration of indentation ball into surfaces with checks compared to surfaces without checks.

Whilst the rupture of wood structural elements reduces the strength properties of Torgvin, the subsequent porous structure of Torgvin and high permeability for liquids provides opportunities for impregnation the material with resins, plastics, and low melting temperature alloys to get composite materials with desirable properties.

\section{(c) Vintorg-metal}

After impregnation of Torgvin with metal alloy, the voids and vessels are filled with metal, increasing the density of the subsequent Vintorg up to $2520-4020 \mathrm{~kg} / \mathrm{m}^{3}$ (with an average density of $3275 \mathrm{~kg} / \mathrm{m}^{3}$ ) and density variation (CV\%) of $17.6 \%$. Density variation arises from the high variation in void volumes and vessels. The mass of wood in Vintorg-metal ranges from 15.8 to $28.4 \%$ (average $19.5 \%$ ) of the total material mass. The pure alloy has a density of $7400 \mathrm{~kg} / \mathrm{m}^{3}$.

Results of Vintorg-metal strength tests in comparison to wood and Torguin are shown in Table 3. Vintorg-metal MOR is 1.54 times higher compared to Torgvin and 1.59 times weaker than the original wood. Vintorg-metal MOE is 1.63 times higher than Torgvin and 1.08 times weaker than the original wood. Vintorg-metal hardness is 2.21 times higher than Torgvin and 2.42 times weaker than the original wood. 
Table 3. Vintorg-metal strength in comparison to wood and Torguin

\begin{tabular}{|c|c|c|c|c|c|c|c|c|c|}
\hline & \multicolumn{3}{|c|}{ MOR, MPa } & \multicolumn{3}{c|}{ MOE, MPa } & \multicolumn{3}{c|}{ Hardness, MPa } \\
\hline $\begin{array}{c}\text { Load application } \\
\text { directions }\end{array}$ & Wood & Torgvin & $\begin{array}{c}\text { Vintorg } \\
- \text { metal }\end{array}$ & Wood & Torgvin & $\begin{array}{c}\text { Vintorg } \\
- \text { metal }\end{array}$ & Wood & Torgvin & $\begin{array}{c}\text { Vintorg } \\
\text { - metal }\end{array}$ \\
\hline Radial (R) & 119 & 52 & 79 & 12390 & 7560 & 10300 & 47 & 17 & 31 \\
\hline Tangential (T) & 117 & 42 & 68 & 9150 & 4740 & 9710 & 45 & 20 & 52 \\
\hline $\begin{array}{c}\text { Transverse (CR) - } \\
\text { average of the radial } \\
\text { (R) and tangential (T) }\end{array}$ & 118 & 48 & 74 & 10770 & 6150 & 10005 & 46 & 19 & 42 \\
\hline
\end{tabular}


Vintorg-metal density increases from 2520 to $4020 \mathrm{~kg} / \mathrm{m}^{3}$ (by 1.6 times) leading to average MOR and MOE increases of only 10\%. Hardness is increased in the radial direction by $70 \%$ and in tangential direction only by $14 \%$.

The alloy fills voids and vessels in Torgvin and forms a metal-wood structure, where the material skeleton is essentially wood (Figure 7). Alloy provides some strength to the voids and vessels but the wood skeleton carries the main load. Therefore, an increase in alloy quantity in Vintorg-metal by 1.6 times does not significantly improve the MOR and MOE. The alloy used in this study is very soft compared to other low melting temperature metal alloys. Therefore, it can be expected that the use of other alloys can make Vintorg-metal stronger then wood.

Vintorg-metal has new properties compared to natural wood: high electro-conductivity, high thermo-conductivity, very high density, different shrinkage and swelling properties, and different acoustic properties. Assessment of these properties requires a special study. Vintorg-metal has original surface patterns due to wood-metal structure, which is significantly influenced by the original technological attributes of the wood species. This provides opportunities for using Vintorg metal as a decorative material or perhaps for specialised jewellery.

\section{Conclusion}

MW modification of Blue gum converts wood into a highly porous material Torguin with numerous cavities mainly in the radial longitudinal planes. MW modification of the wood structure significantly changes the physical and mechanical properties of wood. Torgvin strength properties (MOR, MOE, and surface hardness) are reduced by 1.8 to 2.4 times compared to natural wood. More significant MOR and MOE reductions arise in the tangential compared to radial direction. The very high permeability of Torgvin facilitates its use as an intermediate material for Vintorg manufacture by impregnating the material with suitable resins, plastics or metal alloys. 
Blue-gum Torgvin impregnated with metal alloy (Company Belmont alloy No. 2431, bismuth/lead/tin/cadmium) converts the material to Vintorg-metal. The alloy fills the voids and vessels in Torguin and forms a metal-wood structure, where the material skeleton consists of wood. Alloy changes the physical properties of Torguin. Vintorg-metal MOR and MOE are increased by about 1.6 times compared to Torgvin but are still weaker compared to the original wood.

Vintorg-metal has new properties compared to natural wood: high electro-conductivity, high thermo-conductivity, very high density, different shrinkage and swelling properties, and different acoustic properties. Characterization of these properties requires a special study. A study of material properties of Vintorg manufactured using different alloys and new physical properties should potentially open up new fields of applications. Vintorg-metal has original decorative surface patterns due to the wood-metal structure which provides opportunities for using the material in decorative applications.

\section{References}

[1] Australian Standard ASTM D143-94, Standard Test Method for Small Clear Specimens of Timber. (Reapproved 2007).

[2] G. Torgovnikov and P. Vinden, High intensity microwave wood modification for increasing permeability, Forest Product Journal 59(4) (2009), 84-92.

[3] Torgvin - Trade Mark 973802, Class 19 - Building materials; Class 20 - Furniture, goods of wood. Date of Acceptance 17.02.2004. Owner: The University of Melbourne, Australia.

[4] P. Vinden, G. Torgovnikov, A. Shaginov and J. Hann, Microwave Manufacturing of Solid Wood Composite from Paulownia fortunei and Paulownia elongate, (Conference paper), September 24-26, 2008, Espoo, Finland, International Panel Product Symposium, Proceedings, pp. 211-219.

[5] P. Vinden, J. Romero and G. Torgovnikov, A Method for Increasing the Permeability of Wood. US Patent No. 6,596,975 (2003).

[6] Vintorg - Trade Mark 973805, Class 19 - Building materials, Class 20 - Furniture, goods of wood. Date of Acceptance 17.02.2004. Owner: The University of Melbourne, Australia. 